\title{
AMAR
}

AMAR (Andalas Management Review)

Vol. 4, No. 2 (2020) 32-45

The Management Institute, Faculty of Economics, Universitas Andalas

ISSN (Print) 2476-9282 | ISSN (Online) 2548-155X

\section{Pengaruh Stres Kerja dan Kepuasan Kerja Terhadap Komitmen Organisasi pada PT Semen Baturaja Tbk.}

\author{
Hana Lestari Ningsih', Badia Perizade ${ }^{2}$, Agustina Hanafi ${ }^{3}$, Marlina Widiyanti ${ }^{4}$ \\ ${ }^{1}$ Master of Management, Sriwijaya University \\ Email: hanalestari34@gmail.com \\ ${ }^{2}$ Master of Management, Sriwijaya University \\ Email: badiaperizade1953@gmail.com \\ ${ }^{3}$ Master of Management, Sriwijaya University \\ Email:agustinahanafi29@gmail.com \\ ${ }^{4}$ Master of Management, Sriwijaya University \\ Email:marlinawidiyanti.manajemen@gmail.com
}

\begin{abstract}
ABSTRAK
Penelitian ini dilakukan bertujuan untuk mengetahui pengaruh stres kerja dan kepuasan kerja terhadap komitmen organisasi karyawan PT Semen Baturaja Tbk. Populasi dalam penelitian ini adalah seluruh karyawan tetap PT Semen Baturaja (Persero) Tbk tahun 2020 sebanyak 894 karyawan. Sampel yang digunakan dalam penelitian ini adalah karyawan pada Division Strategic Planning \& Corporate Performance Management, Division Sales, Division Marketing dan Division Logistic yaitu sebanyak 107 karyawan yang didapatkan melalui teknik purposive sampling. Metode pengumpulan data menggunakan kuesioner dan teknik pengolahan data menggunakan analisis regresi linier berganda. Hasil dari analisis regresi linier berganda menunjukkan bahwa stres kerja berpengaruh signifikan terhadap komitmen organisasi karyawan pada PT Semen Baturaja (Persero) Tbk, demikian pula kepuasan kerja berpengaruh signifikan terhadap komitmen organisasi karyawan pada PT Semen Baturaja (Persero) Tbk. Kepuasan kerja merupakan variabel yang dominan dalam mempengaruhi komitmen organisasi. Kepuasan kerja perlu dioptimalkan terutama dalam hal pemberian gaji karyawan dan kesempatan promosi. Dengan sesuaianya harapan karyawan dan realita di organisasi serta stres kerja yang bisa dikelola dengan baik maka dapat mempengaruhi komitmen organisasi karyawan.
\end{abstract}

Kata Kunci: Stres Kerja, Kepuasan Kerja, Komitmen Organisasi

\section{PENDAHULUAN}

Pada beberapa tahun ini industri semen sedang mengalami kondisi kelebihan produksi (oversupply) seperti yang dikutip dari artikel CNBC Indonesia (2018), oversupply masih dapat terjadi 3-5 tahun ke depan. Pada keadaan oversupply ini tentunya masingmasing perusahaan bersaing untuk merebut pasar sebanyak-banyaknya, misalnya PT Semen Indonesia Tbk yang merupakan induk atau holding dari perusahaan-perusahaan semen milik negara (BUMN) di Indonesia dan satu perusahaan serupa di luar negeri, yang 
pada tahun 2018 telah resmi mengakuisisi 80,6\% kepemilikan saham PT Holcim Indonesia Tbk, seperti yang disebutkan pada CNBC Indonesia (2018).

Selanjutnya, PT Semen Baturaja Tbk (SMBR) memiliki strategi tersendiri dalam menghadapi kondisi oversupply tersebut, seperti yang dikutip pada Kontan (2019), PT Semen Baturaja Tbk telah menyiapkan langkah dalam menghadapi kondisi oversupply semen domestik saat ini, yakni SMBR akan tetap memperkuat distribusi dan logistik dengan implementasi distribution center di wilayah Sumatra Selatan, Lampung, Jambi, Bengkulu dan Bangka Belitung serta fokus pada peningkatan pemasaran dan promosi bellow the line strategy yang dilakukan di tingkat ritel dan konsumen. Selanjutnya strategi yang dilakukan PT Semen Baturaja Tbk ini adalah terus menggenjot segmen bisnis hilir di tengah persoalan kelebihan pasok atau oversupply di pasaran dalam negeri. Adapun beberapa segmen bisnis hilir yang sudah dijajal di antaranya meliputi bisnis tanah liat alias white clay, mortar, bata ringan, dan bata porous. Tidak hanya berfokus pada white clay, SMBR juga tengah berupaya untuk meningkatkan volume penjualan berbagai varian produk mortar yang telah tersedia seperti mortar acian, plesteran, pasangan bata ringan, perekat keramik, dan acian putih.

Berbagai strategi yang sudah dilakukan oleh perusahan-perusahan pada industri semen tersebut memiliki hasil pada volume penjualan tahun 2019 yang dapat kita lihat pada Tabel 1.

Tabel 1

Realisasi Penjualan Semen Tahun 2019

\begin{tabular}{llll}
\hline Industri Semen & Realisasi 2019 & Realisasi 2018 & Persentase (\%) \\
\hline PT Semen Indonesia Tbk & 42,61 juta ton & 33,16 juta ton & Naik 28,46 \\
PT Indocement Tunggal & 18,1 juta ton & 18 juta ton & Naik 0,56 \\
Prakarsa Tbk & & & \\
PT Semen Baturaja Tbk & 2.119 .772 ton & 2.189 .357 ton & Turun 3,18 \\
\hline
\end{tabular}

Sumber: www.kontan.co.id

Sepanjang tahun 2019, secara umum penjualan PT Semen Indonesia Tbk sepanjang 2019 naik 28,46\%. Selanjutnya, PT Indocement Tunggal Prakarsa Tbk (INTP) sepanjang 2019 mencatatkan kenaikan penjualan 0,56\% dari realisasi 2018. Sementara itu, penjualan PT Semen Baturaja Tbk (SMBR) tercatat turun 3,18 \% dari realisasi tahun 2018 yang semula 2.189.357 ton semen menjadi 2.119.772 ton semen.

Berbagai strategi yang dilakukan oleh perusahaan-perusahaan di industri semen, tidak terlepas dari usaha para karyawannya. Setiap divisi dalam perusahaan saling bahu 
membahu menghadapi kondisi oversupply ini, hal tersebut merupakan salah satu faktor yang menyebabkan stres pada karyawan PT Semen Baturaja Tbk. karyawan dituntut untuk bekerja keras dalam mencapai target penjualan agar keuangan perusahaan tetap stabil ditengah kondisi oversupply, jika penjualan menurun terus menerus maka keuangan perusahaan akan defisit. Ditengah keadaan industri semen yang oversupply saat ini, tuntutan tugas Division Strategic Planning \& Corporate Performance Management, Division Sales, Division Marketing dan Division Logistic menjadi lebih tertantang dalam mewujudkan strategi perusahaan. Pada Division Sales dan Division Marketing, kedua divisi ini sama-sama memiliki target untuk mencapai pertumbuhan market share. Market share adalah salah satu indikator yang digunakan perusahaan dalam mengukur keberhasilan mereka dibanding kompetitornya dalam merebut pasar. Selanjutnya, tugas Division Sales yang lain adalah mencapai target penjualan perusahaan. Menurut Hidayat, Hakim (2018) meningkatnya kompetisi bisnis membuat karyawan merasa tertekan oleh target pekerjaan, sehingga banyak karyawan memilih untuk mengundurkan diri dari pekerjaan mereka. Menurut Moorhead \& Griffin (2013) stres sebagai respons adaptif seseorang terhadap rangsangan yang menempatkan tuntutan psikologis atau fisik secara berlebihan kepada orang tersebut. Selanjutnya, berdasarkan penelitian yang dilakukan oleh Siegrist dan Rodel dalam Karambut, Afnan T, dan Noormijati (2012) stres kerja sangat mempengaruhi perilaku seseorang di dalam organisasi, misalnya komitmennya terhadap organisasi. Semakin seseorang merasa tertekan, akibat ketidaksesuaian atau perubahan yang terjadi dengan kebiasaan sehari-hari akan menyebabkan kelelahan emosional, yang merupakan indikasi dari stres.

Selain stres kerja, ada hal lain yang harus diperhatikan oleh perusahaan yaitu kepuasan kerja karyawannya. Hammer dan Avgar (2005) mengatakan bahwa karyawan akan cenderung meninggalkan organisasi apabila merasa tidak puas dengan iklim kerja dan karakteristik pekerjaan. Semakin tinggi kepuasan kerja seseorang semakin merangsang seseorang untuk berkomitmen terhadap pekerjaannya yang merupakan bentuk dari kecintaannya terhadap pekerjaan tersebut (Falkenburg \& Schyns, 2007).

Organisasi yang kuat harus mampu membuat karyawannya memiliki komitmen yang tinggi pada organisasinya. Komitmen organisasi sangat penting bagi keberlangsungan hidup sebuah perusahaan. Menurut Karambut, Afnan T, dan Noormijati (2012) saat ini pengertian komitmen tak hanya berbentuk kesediaan karyawan untuk setia menetap dalam jangka waktu yang lama di dalam organisasi. Namun mereka mau memberikan yang terbaik kepada organisasi, bahkan bersedia mengerjakan sesuatu melampaui batas yang 
diwajibkan organisasi adalah sesuatu yang lebih penting. Menurut Hidayat, Hakim (2018) mempertahankan komitmen organisasi saat ini merupakan tantangan untuk banyak organisasi, terutama untuk organisasi bisnis dengan tingkat kompetitif tinggi.

Untuk melihat hubungan antara variabel stres kerja, dan kepuasan kerja terhadap komitmen organisasi, banyak penelitian yang telah dilakukan. Antara lain penelitian yang dilakukan oleh Agustina (2002), Sijabat (2011), Karambut, Afnan, dan Noormijati (2012), Krisdiana (2012), Maruf (2013), Rulestari LH, Eryanto (2013), Anugrah, Ngadiman dan Sohidin (2014), Puspitawati dan Riana (2014), Iresa, Utami, dan Prasetya (2015), Putri, Martono (2015), Prabowo, Alamsyah, dan Noermijati (2016), Pratama, Musadieq dan Mayowan (2016), Anuari, Utami, Prasetya (2017), Ariawan dan Sriathi (2017), Tarmizi dan Dewi (2017), Yunita (2018), Lindawati, menemukan bahwa stres kerja berpengaruh negatif terhadap komitmen organisasional dan kepuasan kerja berpengaruh positif terhadap komitmen organisasional.

Hasil penelitian dari Hidayat, Hakim (2018) bertolak belakang dengan hasil penelitian tersebut. Hasil penelitian Hidayat, Hakim (2018) menunjukkan bahwa stres kerja tidak berpengaruh signifikan terhadap komitmen organisasi. Dijelaskan bahwa karyawan dengan tingkat stres yang tinggi memiliki kepuasan kerja dan komitmen yang tinggi pula. Selanjutnya, hasil penelitian yang berbeda, meskipun stres kerja bisa berpengaruh negatif terhadap komitmen organisasi, tetapi pengaruhnya tidak cukup signifikan untuk berkurangnya komitmen organisasi (Assegaf, 2012). Hal tersebut serupa dengan hasil penelitian oleh Fahrani, Wessiani dan Santosa. Hal ini merupakan research gap dalam penelitian ini. Oleh karena itu peneliti ingin mengetahui bagaimana pengaruh stres kerja dan kepuasan kerja karyawan terhadap komitmen organisasi pada PT Semen Baturaja Tbk.

Penelitian ini dilakukan dengan tujuan untuk mencari bukti empiris dari research gap yang ada dengan cara melakukan analisis pengaruh stres kerja dan kepuasan kerja terhadap komitmen organisasi pada karyawan PT Semen Baturaja Tbk dan variabel mana yang dominan dalam mempengaruhi komitmen organisasi karyawan PT Semen Baturaja Tbk.

\subsection{Stres kerja}

Menurut Luthans (2005) stres didefinisikan sebagai respons adaptif terhadap situasi eksternal yang menghasilkan penyimpangan fisik, psikologis, dan atau perilaku pada anggota organisasi. Menurut Moorhead dan Griffin (2013) stres sebagai respons adaptif seseorang terhadap rangsangan yang menempatkan tuntutan psikologis atau fisik secara berlebihan kepada orang tersebut. Menurut Moorhead dan Griffin (2013), banyak hal yang dapat menyebabkan stres yaitu stressor organisasi dan stressor kehidupan. Stressor 
organisasi adalah berbagai faktor di tempat kerja yang dapat menyebabkan stres. Empat rangkaian umum stressor organisasi adalah:

a. Tuntutan Tugas (task demands). Tuntutan tugas adalah stressor yang berkaitan dengan tugas spesifik yang dikerjakan seseorang di dalam organisasi.

b. Tuntutan Fisik (physical demands). Tuntutan Fisik adalah stressor yang berhubungan dengan situasi fisik pekerjaan, seperti kecukupan temperatur dan pencahayaan, serta persyaratan-persyaratan fisik yang diberikan kepada karyawan.

c. Tuntutan Peran (role demands). Peran adalah serangkaian perilaku yang diharapkan sehubungan dengan posisi tertentu dalam sebuah organisasi. Tuntutan peran adalah stressor yang berhubungan dengan peran yang diharapkan untuk dimainkan oleh seseorang. Individu merasakan ekspektasi peran dengan derajat akurasi yang beragam kemudian berusaha untuk mewujudkan peran tersebut. Namun kesalahan dapat muncul dalam proses ini, menghasilkan masalah yang memicu stres yang disebut dengan ambiguitas peran, konflik peran, dan kelebihan beban peran.

d. Tuntutan Antarpersonal (Interpersonal Demands). Tuntutan antarpersonal adalah stressor yang berhubungan dengan tekanan kelompok, kepemimpinan, dan konflik kepribadian. Tekanan kelompok meliputi tekanan untuk membatasi hasil, tekanan untuk mematuhi norma kelompok, dan tidak ada dukungan di dalam kerja tim. Gaya kepemimpinan juga dapat menyebabkan stres meliputi metode memimpin yang tidak tegas, pemimpin yang terlalu kaku dan sebagainya.

\subsection{Kepuasan Kerja}

Luthans (2005) menyebutkan bahwa kepuasan kerja merupakan keadaan emosi yang senang atau emosi yang positif yang berasal dari penilaian kerja atau pengalaman kerja seseorang. Terdapat lima faktor yang mempengaruhi kepuasan kerja, yaitu (Luthans, 2005):

a. Pekerjaan itu sendiri (Work it self). Pekerjaan dapat memberikan kepuasan kerja tersendiri seperti pekerjaan dengan tugas yang menarik, pekerjaan yang bermanfaat dan bernilai, dapat membuka kesempatan untuk belajar, dan kesempatan untuk menerima tanggung jawab.

b. Gaji (Pay). Gaji adalah sejumlah upah kerja atau balas jasa yang diterima berdasarkan waktu yang telah ditentukan dan tingkat di mana hal ini dipandang sebagai hal yang dianggap pantas dibandingkan dengan orang lain dalam organisasi. 
c. Pengawasan (Supervision). Pengawasan adalah kemampuan penyelia untuk memberikan bantuan secara teknis, memonitoring dan mengevaluasi pekerjaan, serta memberi dukungan di dalam organisasi.

d. Rekan Kerja (Co-workers). Tingkat di mana rekan kerja memberi bantuan secara teknis dan mendukung secara sosial di dalam organisasi.

e. Kesempatan promosi (Promotion opportunities). Kesempatan promosi adalah kesempatan untuk maju dalam organisasi.

\subsection{Komitmen Organisasi}

Menurut Robbins (2015) komitmen organisasi adalah tingkat di mana seorang pekerja mengidentifikasi sebuah organisasi, tujuan dan harapannya untuk tetap menjadi anggota. Luthans (2005) menggolongkan multidimensi dari komitmen perusahaan menjadi tigakomponen model, dan ketiga dimensi tersebut akan digunakan dalam penelitian komitmen organisasional, yaitu:

a. Komitmen afektif (affective commitment), adalah suatu pendekatan emosional dari individu dalam keterlibatan dengan perusahaan, sehingga individu akan merasa dihubungkan dengan perusahaan, berkaitan dengan emosional, identifikasi dan keterlibatan pegawai di dalam suatu perusahaan.

b. Komitmen berkelangsungan (continuance commitment), adalah hasrat yang dimiliki oleh individu, didasarkan pada persepsi pegawai tentang kerugian yang akan dihadapinya jika ia meninggalkan perusahaan, sehingga individu merasa membutuhkan untuk dihubungkan dengan perusahaan.

c. Komitmen normatif (normative commitment), adalah perasaan-perasaan pegawai tentang kewajiban yang harus ia berikan kepada perusahaan, dan tindakan tersebut merupakan hal benar yang harus dilakukan.

\subsection{Penelitian Terdahulu}

Menurut Karambut, Afnan T, dan Noormijati (2012) dampak stres akan berpengaruh terhadap tingkat kepuasan kerja dan komitmen organisasional mereka teori Ini didukung oleh penelitian terdahulu yang diteliti oleh Krisdiana (2012), Rulestari LH, Eryanto (2013), Iresa, Utami, dan Prasetya (2015), Putri, Martono (2015), Anuari, Utami, Prasetya (2017), Ariawan, Sriathi (2017), Tarmizi, Dewi (2017), Yunita (2018), Lindawati.

Kepuasan kerja berpengaruh terhadap komitmen organisasi hal ini dijelaskan Mathis dan Jackson (2011) bahwa kepuasan kerja mencerminkan perasaan seseorang terhadap pekerjaanya, ketika seseorang puas terhadap pekerjaanya maka mereka akan lebih 
berkomitmen terhadap organisasi. Teori tersebut juga didukung oleh hasil penelitian dari Puspitawati dan Riana (2014) dalam penelitiannya di Hotel Bali Hyatt Sanur, menyatakan bahwa kepuasan kerja memiliki pengaruh positif signifikan terhadap komitmen organisasional. Selain itu hasil penelitian serupa juga dilakukan oleh Agustina (2002), Sijabat (2011), Karambut, Afnan, dan Noormijati (2012), Krisdiana (2012), Maruf (2013), Anugrah, Ngadiman dan Sohidin (2014), Prabowo, Alamsyah, dan Noermijati (2016), Pratama, Musadieq dan Mayowan (2016), Ariawan dan Sriathi (2017), Tarmizi dan Dewi (2017), Hakim dan Hidayat (2018), Yunita (2018), Fahrani, Wessiani dan Santosa

\subsection{Kerangka Pikir dan Hipotesis}

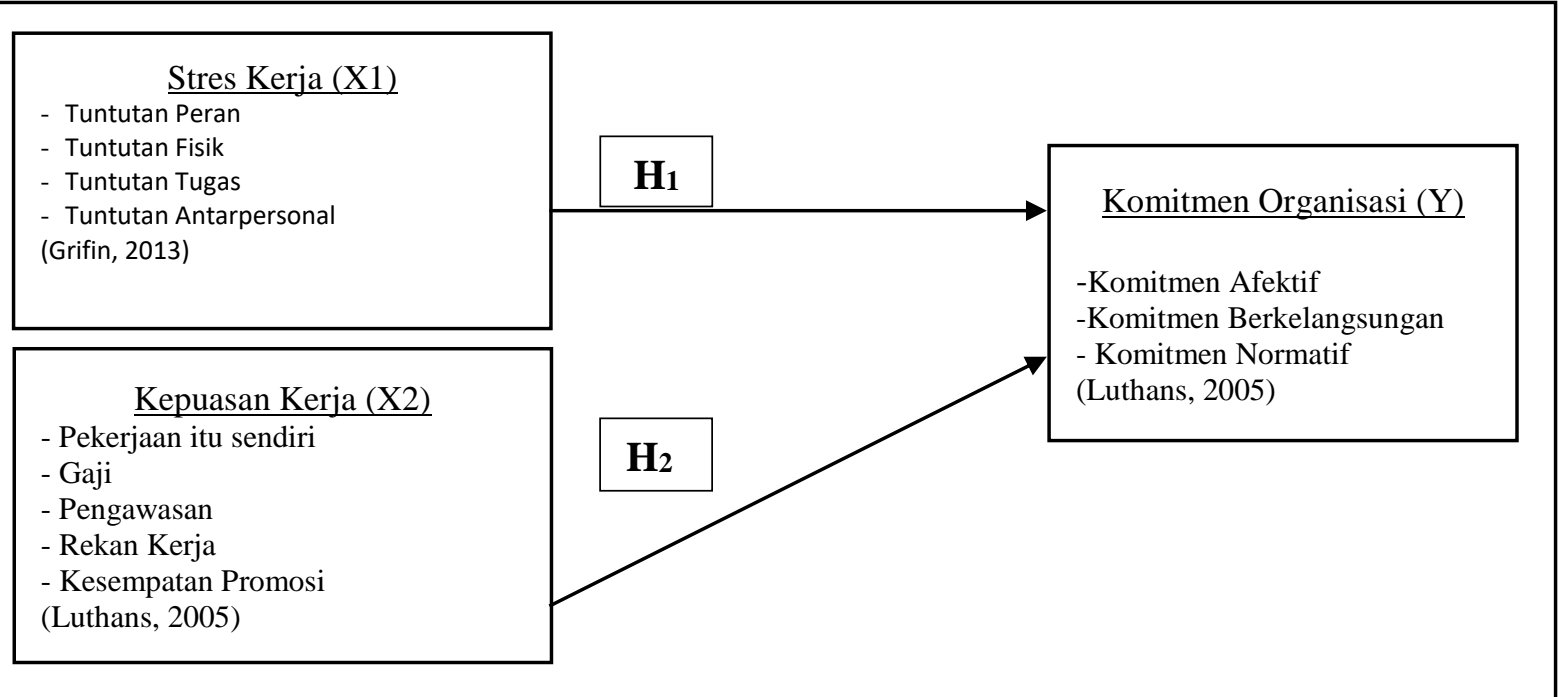

Gambar 1. Kerangka Konseptual

Berdasarkan dari teori permasalahan dan tujuan, maka hipotesis dalam penelitian ini sebagai berikut:

$\mathrm{H}_{1}$ : Stres kerja berpengaruh signifikan terhadap komitmen organisasi pada karyawan PT Semen Baturaja Tbk.

$\mathrm{H}_{2}$ : Kepuasan kerja berpengaruh signifikan terhadap komitmen organisasi pada karyawan PT Semen Baturaja Tbk.

$\mathrm{H}_{3}$ : Kepuasan kerja berpengaruh dominan terhadap komitmen organisasi pada karyawan PT Semen Baturaja Tbk.

\section{METODE}

\subsection{Jenis Penelitian}


Penelitian ini bersifat penelitian kausal karena bertujuan untuk meneliti hubungan sebab akibat antara variabel independent stres kerja dan kepuasan kerja dan variabel dependent komitmen organisasi.

\subsection{Teknik Pengumpulan Data}

Sumber data yang digunakan dalam penelitian ini adalah data primer. Data primer diperoleh peneliti dengan cara menyebar kuesioner yang diberikan kepada karyawan PT Semen Baturaja Tbk.

\subsection{Populasi dan Sampel}

Populasi dalam penelitian ini adalah karyawan PT Semen Baturaja Tbk yang berjumlah 894 karyawan. Teknik sampling yang digunakan adalah teknik sampling purposive. Dalam hal ini penulis mengambil sampel pada karyawan di divisi-divisi yang dinilai terkait langsung dalam usaha mengatasi kondisi oversupply yang terjadi saat ini, divisi tersebut yaitu Division Strategic Planning $\mathcal{E}$ Corporate Performance Management, Division Sales, Division Marketing dan Division Logistic PT Semen Baturaja Tbk yang berjumlah 107. karyawan.

\subsection{Teknik Analisis Data}

Metode yang digunakan dalam penelitian ini adalah analisis regresi linier berganda. Metode ini berguna untuk mengetahui pengaruh hubungan secara langsung antara dua variabel atau lebih variabel bebas dengan satu variabel terikat maka digunakan teknik analisis regresi linier berganda. Dalam penelitian ini adalah antara variabel stres kerja $\left(\mathrm{X}_{1}\right)$ dan kepuasan kerja $\left(\mathrm{X}_{2}\right)$ dan variabel komitmen organisasi $(\mathrm{Y})$.

\section{HASIL DAN PEMBAHASAN}

3.1. Hasil Analisis Regresi Linier Berganda

Tabel 2

Regresi Linier Berganda

\begin{tabular}{llrrr}
\hline \multirow{2}{*}{ Model } & & \multicolumn{2}{c}{$\begin{array}{c}\text { Coefficients }^{\mathrm{a}} \\
\text { Unstandardized Coefficients }\end{array}$} & $\begin{array}{c}\text { Standardized } \\
\text { Coefficients } \\
\text { Beta }\end{array}$ \\
\cline { 3 - 6 } & & B & Std. Error & \\
\cline { 3 - 6 } & & 35.980 & 5.871 & \\
& (Constant) & -.343 & .143 & -.218 \\
& Stres Kerja & .235 & .076 & .283 \\
\hline
\end{tabular}

Dependent Variable: Komitmen Organisasi Sumber: Data kuesioner yang diolah menggunakan SPSS

Berdasarkan Tabel 2 model persamaan sebagai berikut: 
Komitmen organisasi $=35.980-0.218+0.283+\mathrm{e}$

a. Konstanta (a) sebesar 35.980 mempunyai arti bahwa variabel stres kerja dan kepuasan kerja dianggap tidak ada (0) maka tingkat komitmen organisasi sebesar 35.980 pada karyawan PT Semen Baturaja Tbk

b. Koefisien X1 sebesar -0.218 memiliki koefisien negatif yang bernilai baik dan memiliki arti apabila stres kerja menurun satu satuan maka akan meningkatkan komitmen organisasi sebesar 0.218 .

c. Koefisien X2 sebesar 0.283 mempunyai arti bahwa variabel kepuasan kerja mempunyai pengaruh yang positif terhadap komitmen organisasi dengan koefisien sebesar 0.283, yang berarti apabila kepuasan kerja meningkat satu satuan maka akan meningkatkan komitmen organisasi sebesar 0.283.

3.2. Hasil Uji Koefisien Korelasi (r) dan Koefisien Determinasi $\left(\mathrm{R}^{2}\right)$

Tabel 3.

Regresi Linier Berganda

Model Summary

\begin{tabular}{ccccc}
\hline Model & $\mathrm{R}$ & $\mathrm{R}$ Square & $\begin{array}{c}\text { Adjusted R } \\
\text { Square }\end{array}$ & $\begin{array}{c}\text { Std. Error of } \\
\text { the Estimate }\end{array}$ \\
\hline 1 & $.372^{\mathrm{a}}$ & .139 & .122 & 4.96168 \\
\hline
\end{tabular}

Predictors: (Constant), Kepuasan Kerja, Stres Kerja

Sumber: Data kuesioner yang diolah menggunakan SPSS

Berdasarkan Tabel 3 menunjukkan nilai R sebesar 0,372 yang berarti hubungan antara stres kerja dan kepuasan kerja terhadap komitmen organisasi sebesar 37.2\%, artinya memiliki hubungan yang lemah. Nilai koefisien determinasi sebesar 0,139 menunjukan bahwa variabel stres kerja dan kepuasan kerja memiliki kemampuan untuk menjelaskan variabel komitmen organisasi karyawan PT. Semen Baturaja Tbk sebesar 13,9\%. Sedangkan sisanya sebesar $86,1 \%$ dijelaskan oleh variabel bebas lain yang tidak diteliti dalam penelitian ini, yaitu konflik peran (Assegaf, 2005; Rulestari LH, Eryanto, 2013), kecerdasan emosional (Karambut, Afnan T, dan Noormijati, 2012), konflik kerja (Iresa, Utami, dan Prasetya, 2015), karakteristik pekerjaan dan pengembangan karir (Putri, Martono, 2015), kompensasi (Prabowo, Alamsyah dan Noermijati, 2016), komunikasi interpersonal (Lindawati), motivasi kerja (Anuari, Utami, Prasetya, 2017), work life balance (Yunita, 2018), karakteristik individu (Fahrani, Wessiani, Santosa).

3.3. Hasil Uji Parsial Variabel (Uji t)

Tabel 4.

Hasil Uji Parsial Variabel (Uji-t) 


\begin{tabular}{lrrr}
\hline Variabel & \multicolumn{1}{c}{$t_{\text {tabel }}$} & \multicolumn{1}{l}{ thitung } & \multicolumn{1}{l}{ Sig. } \\
\hline (Constant) & & 6.128 & .000 \\
Stres Kerja & 1.983 & -2.391 & .019 \\
Kepuasan Kerja & 1.983 & 3.099 & .002 \\
\hline
\end{tabular}

Dependent Variable: Komitmen Organisasi

Sumber: Data kuesioner yang diolah menggunakan SPSS

Berdasarkan hasil uji parsial (uji t) pada Tabel 4 di atas, untuk kedua variabel bebas dijelaskan sebagai berikut:

a. Pengaruh Stres Kerja terhadap Komitmen Organisasi. Berdasarkan hipotesis yang pertama yaitu: $\mathrm{H}_{1}$ : Stres kerja berpengaruh signifikan terhadap komitmen organisasi pada karyawan PT Semen Baturaja Tbk. Dapat kita lihat hasil uji $t$ variabel stres kerja, diperoleh tingkat signifikansi 0,019 yaitu lebih kecil dari nilai probabilitas atau 0,019<0,05 dan nilai thitung - 2,391 > tabel 1,983. Maka dapat dikatakan hipotesis pertama diterima yaitu stres kerja berpengaruh signifikan terhadap komitmen organisasi pada karyawan PT Semen Baturaja Tbk.

b. Pengaruh Kepuasan Kerja terhadap Komitmen Organisasi. Berdasarkan hipotesis yang kedua yaitu: $\mathrm{H}_{2}$ : Kepuasan kerja berpengaruh signifikan terhadap komitmen organisasi pada karyawan PT Semen Baturaja Tbk. Dapat kita lihat hasil uji t variabel kepuasan kerja diperoleh tingkat signifikansi 0,02 lebih kecil dari nilai probabilitas 0,05 atau 0,02<0,05 dan nilai thitung 3,099 > tabel 1,983. Maka dapat dikatakan hipotesis yang kedua diterima yaitu kepuasan kerja berpengaruh signifikan terhadap komitmen organisasi pada karyawan PT Semen Baturaja Tbk.

c. Kepuasan Kerja Berpengaruh Dominan terhadap Komitmen Organisasi. Berdasarkan hipotesis yang ketiga yaitu: $\mathrm{H}_{3}$ Kepuasan kerja berpengaruh dominan terhadap komitmen organisasi pada karyawan PT Semen Baturaja Tbk. Pada Tabel 4 dapat diketahui variabel kepuasan kerja merupakan variabel yang dominan dalam mempengaruhi komitmen organisasi, karena memiliki nilai $t_{\text {hitung }}$ 3,099 terbesar dengan tingkat signifikansi terkecil 0,02 dibandingkan dengan $t_{\text {hitung }}$ dan tingkat signifikansi dari stres kerja. Maka dapat dikatakan hipotesis yang ketiga diterima yaitu kepuasan kerja berpengaruh dominan terhadap komitmen organisasi pada karyawan PT Semen Baturaja Tbk.

\subsection{Pembahasan}

a. Pengaruh Stres Kerja terhadap Komitmen Organisasi. Berdasarkan hasil uji t variabel stres kerja dapat disimpulkan bahwa $\mathrm{H}_{1}$ diterima yaitu stres kerja berpengaruh 
signifikan terhadap komitmen organisasi pada karyawan PT Semen Baturaja Tbk. Hal ini menunjukkan bahwa stres kerja yang dialami karyawan akan mempengaruhi komitmen pada organisasi. Hal tersebut juga disebutkan oleh Fontana dalam Lina Anatan (2009) berpendapat bahwa, "Dampak stres adalah organizational problem meliputi tingkat kepuasan kerja menurun, komitmen dan loyalitas terhadap organisasi menurun dan produktivitas kerja menurun, sehingga mengakibatkan tingkat absensi dan turnover meningkat". Hasil penelitian ini sesuai dengan hasil penelitian terdahulu yang diteliti oleh Karambut, Afnan T, dan Noormijati (2012), Krisdiana (2012), Rulestari LH, Eryanto (2013), Iresa, Utami, dan Prasetya (2015), Putri, Martono (2015), Anuari, Utami, Prasetya (2017), Tarmizi, Dewi (2017), Ariawan, Sriathi (2017), Yunita (2018), Lindawati.

b. Pengaruh Kepuasan Kerja terhadap Komitmen Organisasi. Berdasarkan hasil uji t variabel kepuasan kerja dapat disimpulkan bahwa $\mathrm{H}_{2}$ diterima yaitu kepuasan kerja berpengaruh signifikan terhadap komitmen organisasi pada karyawan PT Semen Baturaja Tbk. Maka dapat disimpulkan bahwa kepuasan kerja berpengaruh positif dan signifikan terhadap komitmen organisasi karyawan PT Semen Baturaja Tbk. Jika kepuasan kerja meningkat maka akan meningkatkan komitmen organisasi. Kepuasan kerja juga merupakan variabel yang dominan dalam mempengaruhi komitmen organisasi pada penelitian ini. Menurut Luthan (2005) terdapat 5 faktor atau dimensi yang mempengaruhi kepuasan kerja yaitu pekerjaan itu sendiri, gaji, pengawasan, rekan kerja dan kesempatan promosi. Pada penelitian ini peneliti memakai 5 dimensi tersebut untuk meneliti pengaruh kepuasan kerja terhadap komitmen organisasi. Jika lima dimensi tersebut terus ditingkatkan oleh perusahaan, maka tingkat komitmen organisasi akan meningkat juga. Hasil penelitian ini juga sesuai dengan hasil penelitian Puspitawati dan Riana (2014) dalam penelitiannya di Hotel Bali Hyatt Sanur, menyatakan bahwa kepuasan kerja memiliki pengaruh positif signifikan terhadap komitmen organisasional. Selain itu hasil penelitian serupa juga dilakukan oleh Agustina (2002), Sijabat (2011), Krisdiana (2012), Karambut, Afnan, dan Noormijati (2012), Maruf (2013), Anugrah, Ngadiman dan Sohidin (2014), Prabowo, Alamsyah, dan Noermijati (2016), Pratama, Musadieq dan Mayowan (2016), Ariawan dan Sriathi (2017), Tarmizi dan Dewi (2017), Hakim dan Hidayat (2018), Yunita (2018), Fahrani, Wessiani dan Santosa. 
c. Kepuasan Kerja Berpengaruh Dominan terhadap Komitmen Organisasi. Pada Tabel 4 dapat diketahui variabel kepuasan kerja memiliki nilai $t_{\text {hitung }} 3,099$ terbesar dengan tingkat signifikansi terkecil 0,02 dibandingkan dengan $t_{\text {hitung }}$ dan tingkat signifikansi dari stres kerja. Maka dapat dikatakan kepuasan kerja berpengaruh dominan terhadap komitmen organisasi pada karyawan PT Semen Baturaja Tbk.

\section{KESIMPULAN DAN IMPLIKASI}

4.1. Kesimpulan

Berdasarkan hasil pembahasan di atas maka dapat diambil kesimpulan sebagai berikut:

a. Stres kerja $\left(\mathrm{X}_{1}\right)$ berpengaruh signifikan terhadap komitmen organisasi karyawan PT Semen Baturaja Tbk.

b. Kepuasan kerja $\left(\mathrm{X}_{2}\right)$ berpengaruh signifikan terhadap komitmen organisasi karyawan PT Semen Baturaja Tbk.

c. Kepuasan kerja $\left(\mathrm{X}_{2}\right)$ merupakan variabel yang dominan dalam mempengaruhi komitmen organisasi.

\subsection{Implikasi Penelitian}

Hasil penelitian ini memiliki akibat langsung atau konsekuensi terhadap beberapa hal sebagai berikut:

a. Implikasi Teoritis. Dengan upaya-upaya dalam menekan tingkat stres kerja dan pengelolaan stres kerja secara tepat dapat mempengaruhi komitmen organisasi serta harapan harapan yang dimiliki karyawan sesuai dengan realitanya akan mempengaruhi komitmen organisasi karyawan.

b. Implikasi Praktis. Hasil penelitian ini digunakan sebagai masukan bagi manajemen perusahaan PT Semen Baturaja (Persero) Tbk untuk memperbaiki dan meningkatkan komitmen organisasi karyawannya melalui pengelolaan stres kerja yang baik dan kepuasan kerja yang dirasakan oleh karyawan.

\section{REFERENSI}

Agustina, Tri Siwi. (2002). Pengaruh Faktor Faktor Kepuasan Kerja Terhadap Komitmen Karyawan Pada Organisasi (Studi Tentang Karyawan Level Supervisor Di Hotel Novotel Surabaya). Universitas Airlangga.

Anatan, dkk. (2009). Manajemen Sumber Daya Manusia dalam Bisnis Modern. Bandung: Alfabeta,

Anuari, R, dkk. (2017). “Pengaruh Konflik Kerja Terhadap Stres Kerja Dan Motivasi Kerja 
Serta Dampaknya Terhadap Komitmen Organisasional (Studi pada Karyawan PT Pelabuhan Indonesia III (Persero) Kantor Pusat". Jurnal Administrasi Bisnis (JAB) | Vol. 42 No.1

Anugrah, dkk. (2014). Hubungan Antara Kepuasan Kerja Dengan Komitmen Organisasional Karyawan Di PT Sari Warna Asli Garment-Surakarta. Universitas Sebelas Maret Surakarta. Jupe UNS, Vol 2, No 2, Hal 148-158

Falkenburg, K., \& Schyns, B. (2007). “Work satisfaction, Organizational commitment and withdrawal behaviours". Management Research News , 30 (10), 708-723.

Ghozali, I. (2013). Aplikasi Analisis Multivariate Dengan Program SPSS (Edisi Ketujuh). Semarang : Badan Penerbit Universitas Dipenegoro.

Hakim, L, dan Agi S. (2018). The Effect of Job Stress and Job Satisfaction on Organizational Commitment. Universitas Swadaya Gunung Jati. Indonesian Journal of Business and Economics Vol. 1 Issue 1

Hammer, T.H. dan Avgar, A. (2005). "The impact of union on job satisfaction, organizational commitment and turnover". Journal of Labour Research, Vol. 26, No. 2, pp. 241-266

Iresa, dkk. (2015). "Pengaruh Konflik Kerja dan Stres Kerja Terhadap Komitmen Organisasional dan Kinerja Karyawan (Studi pada Karyawan PT. Telekomunikasi Indonesia, Tbk Witel Malang)". Jurnal Administrasi Bisnis (JAB) Vol. 23 No. 1

Karambut, C. A. dkk (2012). “Analisis Pengaruh Kecerdasan Emosional, Stres Kerja dan Kepuasan Kerja terhadap Komitmen Organisasional (Studi pada Perawat Unit Rawat Inap RS Panti Waluya Malang)". Jurnal Aplikasi Manajemen, Volume 10, Nomor 3.

Kreitner dan Kinicki, (2005). Perilaku Organisasi, buku 1 dan 2, Salemba Empat Jakarta

Laporan Tahunan 2015-2019 PT Semen Baturaja Tbk. https:/ / semenbaturaja.co.id/laporantahunan-keuangan/. Diakses tanggal 26 Mei 2020.

Luthans, Fred (2005). Perilaku Organisasi Edisi 10. Penerbit Andi

Mathis, R.L dan Jackson. (2011). Human Resource Management. Jakarta: Salemba Empat.

Prabowo, Akhmadi, Arief Alamsyah dan Noermijati (2016). "Pengaruh Kompensasi dan Kepuasan Kerja terhadap Komitmen Organisasional Perawat dan Bidan Kontrak di RS Bhayangkara Hasta Brata Batu Malang". Universitas Brawijaya. Jurnal Aplikasi Manajemen (JAM) Vol 14 No 1

Pratama, dkk. (2016). "Pengaruh Kompensasi Dan Kepuasan Kerja Terhadap Komitmen Organisasional (Studi pada Karyawan KSP Sumber Dana Mandiri Gresik)". Jurnal Administrasi Bisnis (JAB), Vol. 34 No. 1

Putri, dkk. (2015). Pengaruh Karakteristik Pekerjaan, Pengembangan Karir, Dan Stres Kerja Terhadap Komitmen Organisasional. Management Analysis Journal 4 (4)

Robbins, Stephen P. (2015). Perilaku Organisasi. Edisi Ke Enam belas. PT Indeks: Kelompok Gramedia

Rahayu, A C. (2019). Belum mau ekspor, Semen Baturaja siapkan dua pasar baru dalam negeri di 2020. Kontan (Koran), 15 Desember 2019. https:/ /industri.kontan.co.id/news/belum-mau-ekspor-semen-baturaja-siapkan-duapasar-baru-dalam-negeri-di-2020. Di akses tanggal 26 Mei 2020

Rulestri dkk. (2013). Pengaruh Konflik Peran Dan Stres Kerja Terhadap Komitmen Organisasi Di Rumah Sakit TK IV Salak, Bogor. Universitas Negeri Jakarta. Econo Sains- Volume XI, Nomor 2, Agustus 2013 
Saragih, H P. (2018). Sah! Semen Indonesia Akuisisi Holcim Senilai Rp 25,78 T. CNBC $\begin{array}{llll}\text { Indonesia } \quad \text { (Koran), } & 13 & \text { November }\end{array}$ https://www.cnbcindonesia.com/market/20181113063549-17-41825/sah-semenindonesia-akuisisi-holcim-senilai-rp-2578-t. Di akses tanggal 26 Mei 2020.

Saragih, H P. (2018). SMGR Raja Semen Baru di ASEAN yang Bergulat dengan Oversupply. $\begin{array}{lllll}\text { CNBC Indonesia } & \text { (Koran), } & 17 & \text { November }\end{array}$ https:/ / www.cnbcindonesia.com/market/20181117063616-17-42592/smgr-raja-semenbaru-di-asean-yang-bergulat-dengan-oversupply. Di akses tanggal 26 Mei 2020.

Sijabat, J. (2011). Pengaruh Kepuasan Kerja Terhadap Komitmen Organisasi Dan Keinginan Untuk Pindah - Visi, Vo. 19, No.3, Oktober 2011 Hal.592-608

Sopiah. (2008). Perilaku Organisasi. Yogyakarta: CV. Andi Offset

Suryahadi, A. (2020). Penjualan Semen Indonesia Group (SMGR) per Januari 2020 mencapai 3,35 juta ton. Kontan (Koran), 03 Maret 2020. https:/ / investasi.kontan.co.id/news/ penjualan-semen-indonesia-group-smgr-perjanuari-2020-mencapai-335-juta-ton. Di akses tanggal 26 Mei 2020.

Suryahadi, A. (2020). Penjualan semen nasional naik 1,21\%, simak realisasi penjualan empat emiten semen. Kontan (Koran), $03 \quad$ Maret 2020. https:/ investasi.kontan.co.id/news/ penjualan-semen-nasional-naik-121-simakrealisasi-penjualan-empat-emiten-semen. Di akses tanggal 26 Mei 2020.

Subiantoro, R. (2018). Alasan Semen Indonesia Akuisisi Holcim Rp 13,47 T. CNBC Indonesia (Koran),

https:/ / www.cnbcindonesia.com/market/20181113085723-17-41846/alasan-semenindonesia-akuisisi-holcim-rp-1347-t. Di akses tanggal 26 Mei 2020.

Sugiharti, I. (2019). Penjualan Semen Baturaja (SMBR) mencapai 65\% target hingga September 2019. Kontan (Koran), 22 Oktober 2019. https:/ /investasi.kontan.co.id/news/penjualan-semen-baturaja-smbr-mencapai-65target-hingga-september-2019. Di akses tanggal 26 Mei 2020

Sugiyono. (2012). Metode Penelitian Bisnis. Cetakan ke-16. Bandung: CV. ALFABETA Steers, dkk (1991). Motivation and Work Behavior. Fifth Edition. Mc. Graw-Hill Edition Tarmizi, dkk. (2017). “Pengaruh Stres Kerja Terhadap Kepuasan Dan Komitmen Karyawan: Studi Kasus PT. FEI". Jurnal Riset Manajemen dan Bisnis (JRMB) Fakultas Ekonomi UNIAT. Vol.2, No.3, Oktober 2017: 315 - 322.

Testa, M.R. (2001). “Organizational commitment, job satisfaction, and effort in the service environtment", Journal of Psychology, Vol. 135, No. 2, pp. 226-236

Puspitawati, dkk (2014), "Pengaruh Kepuasan Kerja Terhadap Komitmen Organisasional Dan Kualitas Layanan", Fakultas Ekonomi dan Bisnis Universitas Udayana (UNUD), Bali, Indonesia. Jurnal Manajemen Strategi Bisnis dan Kewirausahaan Vol.8 No.1,

Yunita, P I. (2018), “Komitmen Organisasi Pada Tenaga Operasional: Peran Work-Life Balance, Stres Kerja, dan Kepuasan Kerja, Fakultas Ekonomi dan Bisnis, Universitas Pendidikan Nasional (Undiknas) Denpasar". Jurnal Ilmiah Manajemen \& Bisnis Volume 3, No. 1 . 